\title{
Confirmation of the genetic association of CTLA4 and PTPN22 with ANCA-associated vasculitis
}

\author{
Edward J Carr ${ }^{1,2}$, Heather A Niederer1,2, Julie Williams ${ }^{3}$, Lorraine Harper ${ }^{3}$, \\ Richard A Watts ${ }^{4}$, Paul A Lyons ${ }^{1,2}$ and Kenneth GC Smith*1,2
}

\begin{abstract}
Address: ${ }^{1}$ Cambridge Institute for Medical Research, University of Cambridge School of Clinical Medicine, Addenbrooke's Hospital, Hills Road, Cambridge CB2 OXY, UK, 2Department of Medicine, University of Cambridge School of Clinical Medicine, Addenbrooke's Hospital, Hills Road, Cambridge CB2 OXY, UK, ${ }^{3}$ Division of Infection and Immunity, Medical School, University of Birmingham, Birmingham B15 2TT, UK and ${ }^{4}$ School of Medicine, Health Policy and Practice, University of East Anglia, Norwich NR4 7TJ, UK

Email: Edward J Carr - ejc58@cam.ac.uk; Heather A Niederer - hab37@cam.ac.uk; Julie Williams - julie.williams@uhb.nhs.uk; Lorraine Harper - l.harper@bham.ac.uk; Richard A Watts - richard.watts@ipswichhospital.nhs.uk; Paul A Lyons - pal34@cam.ac.uk; Kenneth GC Smith* - kgcs2@cam.ac.uk

* Corresponding author

Published: I December 2009

BMC Medical Genetics 2009, 10:121 doi:10.1186/1471-2350-10-121

Received: 28 July 2009

Accepted: I December 2009

This article is available from: http://www.biomedcentral.com/I47I-2350/10/I2I

(C) 2009 Carr et al; licensee BioMed Central Ltd.

This is an Open Access article distributed under the terms of the Creative Commons Attribution License (http://creativecommons.org/licenses/by/2.0), which permits unrestricted use, distribution, and reproduction in any medium, provided the original work is properly cited.
\end{abstract}

\begin{abstract}
Background: The genetic contribution to the aetiology of anti-neutrophil cytoplasmic antibody (ANCA)-associated vasculitis (AAV) is not well defined. Across different autoimmune diseases some genes with immunomodulatory roles, such as PTPN22, are frequently associated with multiple diseases, whereas specific HLA associations, such as HLA-B27, tend to be disease restricted. We studied ten candidate loci on the basis of their immunoregulatory role and prior associations with type I diabetes (TID). These included PTPN22, CTLA4 and CD226, which have previously been associated with AAV.

Methods: We genotyped the following II SNPs, from 10 loci, in 64I AAV patients using TaqMan genotyping: rs247660I in PTPN22, rs 1990760 in IFIHI, rs3087243 in CTLA4, rs2069763 in IL2, rs 10877012 in CYP27BI, rs2292239 in ERBB3, rs3184504 in SH2B3, rs 2708716 in CLECI6A, rs 1893217 and rs 478582 in PTPN2 and rs76336I in CD226. Where possible, we performed a metaanalysis with previous analyses.

Results: Both CTLA4 rs3087243 and PTPN22 rs247660I showed association with AAV, $P=6.4 \times$ $10^{-3}$ and $P=1.4 \times 10^{-4}$ respectively. The minor allele (A) of CTLA4 rs3087243 is protective (odds ratio $=0.84$ ), whereas the minor allele (A) of PTPN22 rs247660 I confers susceptibility (odds ratio $=1.40$ ). These results confirmed previously described associations with AAV. After meta-analysis, the PTPN22 rs247660I association was further strengthened (combined $P=4.2 \times 10^{-7}$, odds ratio of 1.48 for the A allele). The other 9 SNPs, including rs76336I in CD226, showed no association with AAV.
\end{abstract}

Conclusion: Our study of TID associated SNPs in AAV has confirmed CTLA4 and PTPN22 as susceptibility loci in AAV. These genes encode two key regulators of the immune response and are 
associated with many autoimmune diseases, including TID, autoimmune thyroid disease, celiac disease, rheumatoid arthritis, and now AAV.

\section{Background}

Anti-neutrophil cytoplasmic antibody (ANCA)-associated vasculitis (AAV) is characterised by small vessel inflammation and necrosis, and autoantibodies against specific neutrophil components (ANCA). The anatomical context of the inflamed vessels determines the signs and symptoms of disease. Renal and lung manifestations are common but any organ or system can be affected. AAV includes the clinical syndromes Wegener's granulomatosis (WG), microscopic polyangiitis (MPA) and ChurgStrauss Syndrome (CSS). AAV is a complex disease with both genetic and environmental factors involved in pathogenesis [1]. The magnitude of the increased familial risk is moderate; it is lower than that seen in systemic lupus erythematosus (SLE) or multiple sclerosis, but similar to that observed in rheumatoid arthritis [2]. The genes responsible for most of this risk are unknown [3]. The only consistent HLA association is with DPB1*0401 [4], however many HLA class I and class II molecules have been associated with disease in small non-replicated studies [3].

There is increasing evidence that susceptibility loci are shared between autoimmune diseases [5]. Therefore, we tested ten candidate loci on the basis of prior replicated associations with T1D [6,7]. The candidate loci tested were PTPN22, IFIH1, CTLA4, IL2, CYP27B1, ERBB3, SH2B3, CLEC16A, PTPN2 and CD226. We have previously reported an association between IL2RA and AAV [8]. Prior evidence supporting association exists for CTLA4, PTPN22 and CD226 [9-12]. CTLA-4 protein expression on CD4 T cells is increased in WG [13]. Several studies tested CTLA4 for association with WG or AAV. The results of these studies are conflicting. Giscombe et al. found an association with a SNP at position -318 (rs5742909) using 32 WG patients and 122 controls [9]. Zhou et al. found an association between WG and shorter (AT)n microsatellite length in the 3'UTR of CTLA4 in a cohort of 117 WG patients and 123 controls [14]. Slot et al. reported an association with a different SNP at position +49 using 102 AAV patients and 192 controls, and no effect at position 318 or the (AT)n microsatellite [10]. Finally, Spriewald et al. reported no association with either of the SNPs -318 or +49 , or the (AT)n microsatellite in the 3'UTR of CTLA4, using $32 \mathrm{WG}$ patients and 91 controls [15]. The prior PTPN22 report used 199 WG cases and 399 healthy controls and rs2476601 [11]. The CD226 report used 642 German WG patients and 1226 controls, but, in a parallel analysis, did not find an association in a cohort of $105 \mathrm{UK}$ WG patients [12]. We sought to confirm these prior asso- ciations, and test the other T1D susceptibility loci, using a collection of 641 AAV cases and 9115 controls.

\section{Methods \\ Patients and controls}

The AAV cohort comprises subjects from four sources, all meeting the Chapel Hill diagnostic criteria [16]:

1. The MRC/Kidney Research UK (KRUK) National DNA Bank for Glomerulonephritis. Individuals were between the ages of 18 and 70 years, were ANCA seropositive, and had biopsy-proven necrotizing glomerulonephritis.

2. The UK vasculitis cohort 2 was recruited from 9 centres in the UK and comprised patients seropositive for ANCA and/or with histological evidence of small vessel vasculitis.

3. Patients recruited from the University of Birmingham. All individuals were ANCA seropositive with firm clinical and/or histological evidence of vasculitis.

4. The Lupus and Vasculitis Service, Addenbrooke's Hospital, Cambridge. All individuals were ANCA seropositive with firm clinical and/or histological evidence of vasculitis.

Genotyping was performed using TaqMan genotyping kits (Applied Biosystems) for each SNP, with fluorescence data captured using an ABI 7900 HT Fast Real-Time PCR System (Applied Biosystems) after 40 cycles of PCR.

Control genotypes for 9115 individuals from the British 1958 Birth Cohort and UK Blood Service were obtained from the Juvenile Diabetes Research Foundation/Wellcome Trust Diabetes and Inflammation Laboratory [6]. This cohort is an expansion of a dataset previously shown to be appropriate for use as UK-wide controls [17]. The 1958 Birth Cohort DNA was collected as part of an ongoing study following all births in England, Scotland and Wales in one week in 1958 http:// www.b58cgene.sgul.ac.uk. This study was approved by the Cambridge Local Research Ethics Committee and by the Oversight Committee of the KRUK DNA Bank.

\section{Statistical analysis}

Statistical analysis was performed using Prism (GraphPad) and R http://www.r-project.org. Genotype tests were performed using $\chi^{2}$ tests for significance on $3 \times 2$ contin- 
gency tables. Allele analyses were performed using $\chi^{2}$ tests for significance on $2 \times 2$ contingency tables. Odds ratios and $95 \%$ confidence intervals were calculated from the same $2 \times 2$ tables. One-sided, log-additive power calculations were performed using Quanto 1.2.4 http:// hydra.usc.edu/gxe/, and the determined allele frequencies and effect sizes. Co-dominant, dominant, over-dominant, recessive and log-additive modelling was performed using the R package SNPassoc [18]. The SNPs genotyped are not within the thirteen genomic loci identified by the Wellcome Trust Case Control Consortium as showing genotype variation by geographic region of the UK [17], and it was therefore not necessary to stratify these analyses by geographical location.

\section{Results}

In this AAV association study, eight of the ten regions tested did not show an AAV association, with $P$ values between 0.19 and 0.75 (table 1). Genotypes for all SNPs did not significantly deviate from Hardy-Weinberg equilibrium in either cases or controls.

Two loci, CTLA4 and PTPN22, marked by rs3087243 and rs2476601 respectively, were associated with disease (tables 1 \&2). rs3087243 in CTLA4 was associated with disease using both genotype and allele tests (allelic $P=6.4$ $\times 10^{-3}$; table 2 ). The minor allele (A) at this locus was protective, with an odds ratio (OR) of 0.84 (95\% confidence interval $0.75-0.95$ ). We also found both genotype and allelic associations between rs2476601 in PTPN22 and AAV (allelic $P=1.4 \times 10^{-4}$; table 2). The minor allele (A) of rs2476601 confers susceptibility with an OR of 1.40 (95\% confidence interval 1.18 - 1.67).

There is a prior study reporting an association between PTPN22 rs2476601 and Wegener's granulomatosis [11]. The results of our meta-analysis (table 3 ), demonstrate a validated association for PTPN22 and AAV (allelic $P=4.2$ $\times 10^{-7}$ ). In both PTPN22 studies the minor allele conferred susceptibility. The combined odds ratio for the minor allele is 1.48 ( $95 \%$ confidence interval $1.27-1.71)$. For a subset of our AAV patients, WG and MPA diagnoses were available. The effect of rs 2476601 is present in both WG and MPA compared with the same control population (WG: $\mathrm{n}=205$, allelic $P=6 \times 10^{-11}, \mathrm{OR}=2.01$; MPA: $\mathrm{n}=$ 74 , allelic $P=4.1 \times 10^{-6}, \mathrm{OR}=2.55$ ).

The prior CTLA4 studies with positive results used SNPs at positions -318 and +49 , rather than rs3087243, precluding a meta-analysis $[9,10]$. We also tested for differential associations in WG or MPA but were unable to demonstrate an association with either of our smaller WG or MPA cohorts alone (data not shown).

The prior CD226 study reported an association with rs763361 in a cohort of German patients, but did not find an association in a collection from the University of Birmingham [12]. We also find no association between

Table I: Allele association testing in AAV of I I SNPs at 10 loci

\begin{tabular}{|c|c|c|c|c|c|c|}
\hline \multirow[t]{2}{*}{ Chr } & \multirow[t]{2}{*}{ Gene } & \multirow[t]{2}{*}{ SNP } & \multicolumn{2}{|c|}{$\begin{array}{l}\text { Controls } \\
n=9115\end{array}$} & \multicolumn{2}{|c|}{$\begin{array}{c}\text { Vasculitis cases } \\
n=64 I\end{array}$} \\
\hline & & & MAF & MAF & $P$ value & OR $(95 \% \mathrm{Cl})$ \\
\hline$|p| 3$ & PTPN22 & rs247660। G>A (R620W) & 0.10 & 0.13 & $1.4 \times 10^{-4}$ & $\begin{array}{c}1.40 \\
(1.18-1.67)\end{array}$ \\
\hline $2 q 24$ & $\mid F I H I$ & rs I990760 T>C (A946T) & 0.39 & 0.40 & 0.47 & $\begin{array}{c}1.05 \\
(0.93-1.18)\end{array}$ \\
\hline $2 q 33$ & CTLA4 & rs3087243 G>A & 0.45 & 0.41 & $6.4 \times 10^{-3}$ & $\begin{array}{c}0.84 \\
(0.75-0.95)\end{array}$ \\
\hline $4 q 27$ & IL2 & rs2069763 G>T & 0.32 & 0.31 & 0.51 & $\begin{array}{c}0.95 \\
(0.82-1.10)\end{array}$ \\
\hline $12 q 13$ & CYP27BI & rs $10877012 \mathrm{G}>\mathrm{T}$ & 0.33 & 0.32 & 0.34 & $\begin{array}{c}0.93 \\
(0.82-1.07)\end{array}$ \\
\hline $12 q 13$ & ERBB3 & rs2292239 A >C & 0.35 & 0.35 & 0.75 & $\begin{array}{c}0.97 \\
(0.86-1.11)\end{array}$ \\
\hline $12 q 24$ & $\mathrm{SH} 2 \mathrm{~B} 3$ & $\mathrm{rs} 3184504 \mathrm{C}>\mathrm{T}(\mathrm{R} 292 \mathrm{~W})$ & 0.48 & 0.49 & 0.56 & $\begin{array}{c}1.04 \\
(0.92-1.17)\end{array}$ \\
\hline $16 p 13$ & CLECI6A & $r s|27087| 6 A>G$ & 0.35 & 0.36 & 0.24 & $\begin{array}{c}1.08 \\
(0.95-1.22)\end{array}$ \\
\hline$|8 p| \mid$ & PTPN2 & $\mathrm{rs} 1893217 \mathrm{~T}>\mathrm{C}$ & 0.17 & 0.19 & 0.19 & $\begin{array}{c}1.12 \\
(0.95-1.31)\end{array}$ \\
\hline$|8 p| \mid$ & PTPN2 & $\begin{array}{c}r s 478582 \\
T>C\end{array}$ & 0.45 & 0.43 & 0.26 & $\begin{array}{c}0.93 \\
(0.83-1.05)\end{array}$ \\
\hline $18 q 22$ & $C D 226$ & $\begin{array}{c}r s 76336 \mathrm{I} \\
\mathrm{C}>\mathrm{T}(\mathrm{G} 307 \mathrm{~S})\end{array}$ & 0.49 & 0.47 & 0.21 & $\begin{array}{c}0.90 \\
(0.77-1.06)\end{array}$ \\
\hline
\end{tabular}


Table 2: Genotype and allele associations for CTLA4 rs3087243 and PTPN22 rs247660 I in AAV

\begin{tabular}{|c|c|c|c|c|c|}
\hline & \multicolumn{2}{|c|}{ Controls } & \multicolumn{2}{|c|}{ AAV cases } & \multirow[b]{2}{*}{$P$ value } \\
\hline & $\mathbf{n}$ & Frequency & $\mathbf{n}$ & Frequency & \\
\hline \multicolumn{6}{|c|}{ CTLA4 rs3087243 } \\
\hline GG & 2726 & 0.30 & 198 & 0.34 & \\
\hline GA & 4453 & 0.49 & 282 & 0.49 & \\
\hline $\mathrm{AA}$ & $|86|$ & 0.21 & 95 & 0.17 & $0.02 *$ \\
\hline G & 9905 & 0.55 & 678 & 0.59 & \\
\hline$A$ & 8175 & 0.45 & 472 & 0.41 & $6.4 \times 10^{-3} * * \S$ \\
\hline \multicolumn{6}{|c|}{ PTPN22 rs247660I } \\
\hline GG & 6044 & 0.82 & 471 & 0.75 & \\
\hline GA & 1298 & 0.18 & 146 & 0.23 & \\
\hline $\mathrm{AA}$ & 70 & 0.01 & 9 & 0.01 & $5.2 \times 10^{-4} *$ \\
\hline G & 13386 & 0.90 & 1088 & 0.87 & \\
\hline$A$ & 1438 & 0.10 & 164 & 0.13 & $1.4 \times 10^{-4} * * \S \S$ \\
\hline
\end{tabular}

\footnotetext{
$* P$ value calculated by $\chi^{2}$ test on $3 \times 2$ contingency table ** $P$ value calculated by $\chi^{2}$ test on $2 \times 2$ contingency table $\S$ Odds ratio $(O R)$ for minor allele $(A)=0.84$

$\S \S \mathrm{OR}$ for minor allele $=1.40$
}

CD226 and AAV patients from the United Kingdom $(P=$ 0.21 , table 1). Excluding AAV patients from the University of Birmingham from our cohort, to minimise any potential confounding effects, does not alter the analysis $(\mathrm{n}=$ 391 , allelic $P=0.38, \mathrm{OR}=0.93,95 \% \mathrm{CI}=0.78-1.10$, power $=27.3 \%)$.

For both CTLA4 rs3087243 and PTPN22 rs2476601, we tested the genotype data (table 2) using several different models of inheritance (co-dominant, dominant, overdominant, recessive and log-additive). No single model had a clearly superior fit at either locus (table 4).

\section{Discussion}

CTLA4 and PTPN22 are now firmly established as AAV susceptibility loci, along with HLA-DPB, with associations confirmed in two separate cohorts. Clarification of the potentially complex role of the CTLA4 locus in AAV, as implied by apparently conflicting prior studies $[9,10,14,15]$, would be provided by a larger, more detailed study of the locus. PTRN3 and AAT are the only other confirmed AAV associations [1].

CTLA4 encodes cytotoxic T lymphocyte antigen 4 (CTLA4), a negative regulator of $\mathrm{T}$ cell activation. Ctla4 $/-$ mice die by 3-4 weeks of age, with lymphadenopathy and splenomegaly, consisting of $\mathrm{T}$ cell expansions expressing activation markers [19], and lymphocytic infiltration and tissue destruction of many organs, including heart and pancreas [20]. Numerous subsequent studies have revealed that CTLA- 4 has complex biology; it is known to bind CD80 and CD86 with higher affinity than CD28

Table 3: Meta-analysis for PTPN22 rs247660I in AAV

\begin{tabular}{|c|c|c|c|c|c|}
\hline & \multicolumn{2}{|c|}{$\begin{array}{c}\text { Controls } \\
\text { this study//Jagiello' }\end{array}$} & \multicolumn{3}{|c|}{$\begin{array}{c}\text { AAV cases } \\
\text { this study//Jagiello I }\end{array}$} \\
\hline & $\stackrel{n}{74 \mid 2 / / 399}$ & Frequency & $\frac{n}{626 / / 199}$ & Frequency & $\begin{array}{l}\text { Combined } \\
P \text { value }\end{array}$ \\
\hline GG & $6044 / / 323$ & $0.82 / / 0.81$ & $47 I / / 142$ & $0.75 / / 0.71$ & \\
\hline GA & $1298 / / 72$ & $0.18 / / 0.18$ & $146 / / 52$ & $0.23 / / 0.26$ & \\
\hline $\mathrm{AA}$ & $70 / / 4$ & $0.01 / / 0.01$ & $9 / / 5$ & $0.01 / / 0.03$ & $2.2 \times 10^{-6 *}$ \\
\hline G & |3386//7|8 & $0.90 / / 0.90$ & $1088 / / 336$ & $0.86 / / 0.84$ & \\
\hline$A$ & $1438 / / 80$ & $0.10 / / 0.10$ & $164 / / 62$ & $0.13 / / 0.16$ & $4.2 \times 10^{-7} * * \S$ \\
\hline
\end{tabular}

I Data from Jagiello et al [I I]

$* P$ value calculated by $\chi^{2}$ test on $3 \times 2$ contingency table

** $P$ value calculated by $\chi^{2}$ test on $2 \times 2$ contingency table

$\S$ OR for minor allele $=1.48$ 
Table 4: Models of inheritance for the CTLA4 rs3087243 and PTPN22 rs247660 I associations in AAV

\begin{tabular}{cccccc}
\hline & Co-dominant & Dominant & $\begin{array}{c}\boldsymbol{P} \text { value of indicated model } \\
\text { Over-dominant }\end{array}$ & Recessive & Log-additive \\
\hline $\begin{array}{c}\text { CTLA4 } \\
\text { rs3087243 } \\
\begin{array}{c}\text { PTPN22 } \\
\text { rs247660 }\end{array}\end{array}$ & 0.02 & 0.03 & 0.92 & 0.02 & $5.8 \times 10^{-3}$ \\
\hline
\end{tabular}

$[21,22]$, it is expressed by both regulatory and effector $\mathrm{T}$ cells, and it is synthesised as soluble and transmembrane isoforms [23] with the majority of CTLA-4 retained intracellularly. Specific deficiency of Ctla4\% in natural Foxp3+CD4+ regulatory $\mathrm{T}$ cells results in spontaneous autoimmune disease [24]. The precise role of CTLA-4 in the maintenance of peripheral tolerance remains unclear, with no unifying model of CTLA-4 function [25]. Human polymorphisms in CTLA4 are associated with several autoimmune diseases, including type 1 diabetes (T1D), Graves' disease [6,26], Hashimoto's thyroiditis [27], celiac disease [28], and rheumatoid arthritis (RA) [29].

CD4 T cells from AAV patients express higher levels of membrane-bound CTLA-4 protein than CD4 T cells from healthy controls [13]. The common G allele of rs3087243, which confers susceptibility to AAV, does not alter expression of full length CTLA4 mRNA [26]. Despite the G allele of rs3087243 associating with a lowered expression of the CTLA4 transcript encoding the soluble form of the protein [26], genotype at rs3087243 does not correlate with soluble CTLA- 4 protein in serum from T1D patients or from autoantibody positive or negative healthy controls [30]. A different SNP, rs5742909, in the CTLA4 promoter region may be associated with expression level [31] and there is some evidence of association with WG [9]. Linkage disequilibrium between rs3087243 and rs5742909 is low ( $\mathrm{r}^{2}$ $=0.074 ;$ CEPH dataset, http://hapmap.ncbi.nlm.nih.gov/ . Thus rs57942909 may have an independent effect to that conferred by rs3087243.

In addition to the effects on the expression of CTLA4 isoforms, the two alleles of rs3087243 are associated with altered $\mathrm{T}$ cell phosphorylation levels [32]. CD4 T cells from carriers of the AAV risk-conferring $G$ allele exhibit greater levels of phospho-LAT, phospho-LCK, phosphoZAP70, and phospho-SLP76 after anti-CD3 treatment. There have been no reported differences in CTLA- 4 protein expression on CD4 T cells between donors of all rs3087243 genotypes. The lower activation threshold of $\mathrm{T}$ cells from carriers of the $\mathrm{G}$ allele of rs3087243 might thus contribute to $\mathrm{T}$ cell activation and autoimmune disease susceptibility. Taken together these data suggest that genotype at rs3087243 could impact upon both the expression of CTLA4 mRNA isoforms and the subsequent level and function of the translated protein.
PTPN22 encodes a second negative regulator of T cell activation, LYP. The SNP rs2476601 is a non-synonymous change substituting arginine for tryptophan at amino acid residue 620. PTPN22 is being increasingly recognised as a central player in $\mathrm{T}$ cell regulation, being a direct target for inhibition by the regulatory $\mathrm{T}$ cell transcription factor Foxp3 [33] and by the T cell modulating mir-181a [34]. The predisposing allele in T1D, RA and AAV is Trp ${ }^{620}$ (the A allele). T cell receptor stimulation of T cells from carriers of the $\operatorname{Trp}^{620}$ allele, resulted in decreased interleukin 2 production due to increased phosphatase activity [35]. The functional implications of this SNP also extend to B cells, where the $\operatorname{Trp}^{620}$ allele reduces activation thresholds in an analogous manner to $\mathrm{T}$ cells, perhaps allowing autoantibody production by $\mathrm{B}$ cells in addition to the effects of the $\operatorname{Trp}^{620}$ allele in T cells [36]. However, whilst mice lacking Pep (the murine ortholog of PTPN22) have spontaneous germinal centre formation, autoantibodies have not been described [37]. While the Trp ${ }^{620}$ PTPN22 allele is associated with susceptibility in many diseases [38], the alternative Arg620 allele confers risk in others (such as Crohn's disease [39]). This underlines the importance of the pathway controlled by PTPN22 in autoimmunity, but indicates distinct regulatory changes in the pathway are involved in different disease states. It has been suggested that the $\operatorname{Trp}^{620}$ allele is implicated in autoimmune diseases associated with autoantibody production, such as AAV or T1D [36], and indeed the Trp ${ }^{620}$ allele of rs2476601 in PTPN22 is associated with both WG and MPA.

CTLA4, PTPN22 and IL2RA are all genes associated with the regulation of $\mathrm{T}$ cell activation, via the modulation of signalling in effector $\mathrm{T}$ cells and the control of regulatory $\mathrm{T}$ cells. All of these genes are associated with multiple autoimmune diseases, including $\mathrm{T} 1 \mathrm{D}$, autoimmune thyroid disease and AAV $[6,8,26,40-42]$. This may in part explain the familial co-segregation seen between some of these diseases, for example between T1D and autoimmune thyroid disease $[26,43]$. AAV however does not show clear evidence for co-segregation with other autoimmune diseases, implying the existence of susceptibility loci unique to AAV pathogenesis. These unique loci, by their nature, are difficult to identify with candidate gene studies, demonstrating the need for a genome-wide association study in AAV. 


\section{Conclusion}

We confirm two associations with AAV in CTLA4 and PTPN22, both important regulators of the immune response. There are now five confirmed AAV susceptibility loci: HLA-DPB1, CTLA4, PTPN22, PRTN3 and AAT.

\section{Competing interests}

The authors declare that they have no competing interests.

\section{Authors' contributions}

KGCS \& PAL conceived and designed the study. JW, LH \& RAW provided access to DNA samples. EJC \& HAN performed the SNP genotyping and its analysis. The manuscript was written by EJC \& KGCS. All authors read and approved the final manuscript.

\section{Acknowledgements}

We are grateful for the participation of all of the patients and control subjects. We acknowledge use of DNA from the MRC/Kidney Research UK National DNA Bank for Glomerulonephritis and Neil Walker for his curation and supply of data from the British 1958 Birth Cohort. We thank Caroline Savage, Lavanya Kamesh and Dwomoa Adu, along with other colleagues in many different institutions for contributions to DNA collections, Christopher Lowe and Deborah Smyth for their technical advice and support and John Todd for his advice and critical review of the manuscript.

This work was funded by the NIHR Cambridge Biomedical Research Centre, the Medical Research Council (MRC), the Wellcome Trust (Programme Grant Number 083650/Z/07/Z), and a combined Wellcome Trust - Juvenile Diabetes Research Foundation grant awarded to John Todd. The Cambridge Institute for Medical Research is in receipt of a Wellcome Trust Strategic Award (079895). EJC was funded by a MRC Doctoral Training Account studentship.

\section{References}

I. Willcocks LC, Lyons PA, Rees AJ, Smith KGC: Pathogenesis of ANCA-associated systemic vasculitis: genetic variation and infections. Arthritis Research \& Therapy 2009 in press.

2. Knight A, Sandin S, Askling J: Risks and relative risks of Wegener's granulomatosis among close relatives of patients with the disease. Arthritis and Rheumatism 2008, 58(I):302-307.

3. Jagiello P, Gross WL, Epplen JT: Complex genetics of Wegener granulomatosis. Autoimmunity Reviews 2005, 4(I):42-47.

4. Heckmann M, Holle JU, Arning L, Knaup S, Hellmich B, Nothnagel M, Jagiello P, Gross WL, Epplen JT, Wieczorek S: The Wegener's granulomatosis quantitative trait locus on chromosome 6p21.3 as characterised by tagSNP genotyping. Annals of the Rheumatic Diseases 2008, 67(7):972-979.

5. Brand O, Gough S, Heward J: HLA, CTLA-4 and PTPN22: the shared genetic master-key to autoimmunity? Expert Reviews in Molecular Medicine 2005, 7(23): I-I5.

6. Todd JA, Walker NM, Cooper JD, Smyth DJ, Downes K, Plagnol V, Bailey R, Nejentsev S, Field SF, Payne F, et al.: Robust associations of four new chromosome regions from genome-wide analyses of type I diabetes. Nature Genetics 2007, 39(7):857-864.

7. Hafler JP, Maier LM, Cooper JD, Plagnol V, Hinks A, Simmonds MJ, Stevens HE, Walker NM, Healy B, Howson JM, et al.: CD226 Gly307Ser association with multiple autoimmune diseases. Genes and Immunity 2009, I O(I):5-10.

8. Carr EJ, Clatworthy MR, Lowe CE, Todd JA, Wong A, Vyse TJ, Kamesh L, Watts RA, Lyons PA, Smith KGC: Contrasting genetic association of IL2RA with SLE and ANCA-associated vasculitis. BMC Medical Genetics 2009, 10:22.

9. Giscombe R, Wang X, Huang D, Lefvert AK: Coding sequence I and promoter single nucleotide polymorphisms in the
CTLA-4 gene in Wegener's granulomatosis. The Journal of Rheumatology 2002, 29(5):950-953.

10. Slot MC, Sokolowska MG, Savelkouls KG, Janssen RG, Damoiseaux JG, Cohen Tervaert JW: Immunoregulatory gene polymorphisms are associated with ANCA-related vasculitis. Clinical Immunology (Orlando, Fla) 2008, I 28(I):39-45.

II. Jagiello P, Aries P, Arning L, Wagenleiter SE, Csernok E, Hellmich B, Gross WL, Epplen JT: The PTPN22 620W allele is a risk factor for Wegener's granulomatosis. Arthritis and Rheumatism 2005, 52(1 2):4039-4043.

12. Wieczorek S, Hoffjan S, Chan A, Rey L, Harper L, Fricke H, Holle JU, Gross WL, Epplen JT, Lamprecht P: Novel association of the CD226 (DNAM-I) Gly307Ser polymorphism in Wegener's granulomatosis and confirmation for multiple sclerosis in German patients. Genes and Immunity 2009, I 0(6):59I-5.

13. Steiner K, Moosig F, Csernok E, Selleng K, Gross WL, Fleischer B, Bröker BM: Increased expression of CTLA-4 (CDI52) by $T$ and B lymphocytes in Wegener's granulomatosis. Clinical and Experimental Immunology 200I, I 26(I): I 43-I50.

14. Zhou Y, Huang D, Paris PL, Sauter CS, Prock KA, Hoffman GS: An analysis of CTLA-4 and proinflammatory cytokine genes in Wegener's granulomatosis. Arthritis and Rheumatism 2004, 50(8):2645-2650.

15. Spriewald BM, Witzke O, Wassmuth R, Wenzel RR, Arnold ML, Philipp T, Kalden JR: Distinct tumour necrosis factor alpha, interferon gamma, interleukin 10 , and cytotoxic $T$ cell antigen 4 gene polymorphisms in disease occurrence and end stage renal disease in Wegener's granulomatosis. Annals of the Rheumatic Diseases 2005, 64(3):457-46I.

16. Jennette JC, Falk RJ, Andrassy K, Bacon PA, Churg J, Gross WL, Hagen EC, Hoffman GS, Hunder GG, Kallenberg CG: Nomenclature of systemic vasculitides. Proposal of an international consensus conference. Arthritis and Rheumatism 1994, 37(2): $187-192$.

17. Wellcome Trust Case Control Consortium: Genome-wide association study of 14,000 cases of seven common diseases and 3,000 shared controls. Nature 2007, 447(7 I 45):66I-678.

18. Gonzalez JR, Armengol L, Sole X, Guino E, Mercader JM, Estivill X, Moreno V: SNPassoc: an R package to perform whole genome association studies. Bioinformatics 2007, 23(5):644-645.

19. Waterhouse P, Penninger JM, Timms E, Wakeham A, Shahinian A, Lee KP, Thompson CB, Griesser H, Mak TW: Lymphoproliferative disorders with early lethality in mice deficient in Ctla-4. Science (New York, NY) 1995, 270(5238):985-988.

20. Tivol EA, Borriello F, Schweitzer AN, Lynch WP, Bluestone JA, Sharpe AH: Loss of CTLA-4 leads to massive lymphoproliferation and fatal multiorgan tissue destruction, revealing a critical negative regulatory role of CTLA-4. Immunity 1995, 3(5):54I-547.

21. Stamper CC, Zhang Y, Tobin JF, Erbe DV, Ikemizu S, Davis SJ, Stahl ML, Seehra J, Somers WS, Mosyak L: Crystal structure of the B7I/CTLA-4 complex that inhibits human immune responses. Nature 200I, 4I 0(6828):608-6II.

22. Zhang X, Schwartz JC, Almo SC, Nathenson SG: Crystal structure of the receptor-binding domain of human B7-2: insights into organization and signaling. Proceedings of the National Academy of Sciences of the United States of America 2003, I 00(5):2586-259I.

23. Oaks MK, Hallett KM, Penwell RT, Stauber EC, Warren SJ, Tector AJ: A native soluble form of CTLA-4. Cellular Immunology 2000, 20I(2): I44-I53.

24. Wing K, Onishi Y, Prieto-Martin P, Yamaguchi T, Miyara M, Fehervari Z, Nomura T, Sakaguchi S: CTLA-4 control over Foxp3+ regulatory T cell function. Science 2008, 322(5899):27I-275.

25. Rudd CE: The reverse stop-signal model for CTLA4 function. Nature Reviews Immunology 2008, 8(2): $153-160$.

26. Ueda H, Howson JM, Esposito L, Heward J, Snook H, Chamberlain G, Rainbow DB, Hunter KM, Smith AN, Di Genova G, et al.: Association of the T-cell regulatory gene CTLA4 with susceptibility to autoimmune disease. Nature 2003, 423(6939):506-5II.

27. Kavvoura FK, Akamizu T, Awata T, Ban Y, Chistiakov DA, Frydecka I, Ghaderi A, Gough SC, Hiromatsu Y, Ploski R, et al:: Cytotoxic Tlymphocyte associated antigen 4 gene polymorphisms and autoimmune thyroid disease: a meta-analysis. The Journal of Clinical Endocrinology and Metabolism 2007, 92(8):3162-3170.

28. Smyth DJ, Plagnol V, Walker NM, Cooper JD, Downes K, Yang JH, Howson JM, Stevens H, McManus R, Wijmenga C, et al:: Shared and 
distinct genetic variants in type I diabetes and celiac disease. The New England Journal of Medicine 2008, 359(26):2767-2777.

29. Daha NA, Kurreeman FA, Marques RB, Stoeken-Rijsbergen G, Verduijn W, Huizinga TW, Toes RE: Confirmation of STAT4, IL2/ IL2I, and CTLA4 polymorphisms in rheumatoid arthritis. Arthritis and Rheumatism 2009, 60(5): I 255-I 260.

30. Purohit S, Podolsky R, Collins C, Zheng W, Schatz D, Muir A, Hopkins $D$, Huang $Y$, She J: Lack of correlation between the levels of soluble cytotoxic T-lymphocyte associated antigen-4 (CTLA-4) and the CT-60 genotypes. Journal of Autoimmune Diseases 2005, 2:8.

31. Wang X, Zhao X, Giscombe R, Lefvert A: A CTLA-4 gene polymorphism at position -318 in the promoter region affects the expression of protein. Genes and Immunity 2002, 3(4):233-234

32. Maier LM, Anderson DE, De Jager PL, Wicker LS, Hafler D: Allelic variant in CTLA4 alters T cell phosphorylation patterns. Proceedings of the National Academy of Sciences of the United States of America 2007, I04(47): |8607-|86|2.

33. Marson A, Kretschmer K, Frampton GM, Jacobsen ES, Polansky JK, Maclsaac KD, Levine SS, Fraenkel E, von Boehmer H, Young RA: Foxp3 occupancy and regulation of key target genes during T-cell stimulation. Nature 2007, 445(7130):93I-935.

34. Li OJ, Chau J, Ebert PJ, Sylvester G, Min H, Liu G, Braich R, Manoharan $M$, Soutschek J, Skare P, et al.: miR- $\mathbf{8} \mathbf{I} \mathrm{a}$ is an intrinsic modulator of $T$ cell sensitivity and selection. Cell 2007, I 29(I): |47-I6I.

35. Vang T, Congia M, Macis MD, Musumeci L, Orrú V, Zavattari P, Nika K, Tautz L, Taskén K, Cucca F, et al.: Autoimmune-associated lymphoid tyrosine phosphatase is a gain-of-function variant. Nature Genetics 2005, 37( I 2): | 317-1319.

36. Arechiga AF, Habib T, He Y, Zhang X, Zhang ZY, Funk A, Buckner JH: Cutting edge: The PTPN22 allelic variant associated with autoimmunity impairs B cell signaling. Journal of Immunology (Baltimore, Md: 1950) 2009, 182(6):3343-3347.

37. Hasegawa K, Martin F, Huang G, Tumas D, Diehl L, Chan AC: PEST domain-enriched tyrosine phosphatase (PEP) regulation of effector/memory T cells. Science (New York, NY) 2004, 303(5658):685-689.

38. Vang T, Miletic AV, Arimura Y, Tautz L, Rickert RC, Mustelin T: Protein tyrosine phosphatases in autoimmunity. Annual Review of Immunology 2008, 26:29-55.

39. Barrett J, Hansoul S, Nicolae DL, Cho JH, Duerr RH, Rioux JD, Brant SR, Silverberg MS, Taylor KD, Barmada MM, et al.: Genome-wide association defines more than $\mathbf{3 0}$ distinct susceptibility loci for Crohn's disease. Nature Genetics 2008, 40(8):955-962.

40. Criswell LA, Pfeiffer KA, Lum RF, Gonzales B, Novitzke J, Kern M, Moser KL, Begovich AB, Carlton VE, Li W, et al.: Analysis of families in the multiple autoimmune disease genetics consortium (MADGC) collection: the PTPN22 620W allele associates with multiple autoimmune phenotypes. American Journal of Human Genetics 2005, 76(4):56I-57I.

4I. Brand OJ, Lowe CE, Heward JM, Franklyn JA, Cooper JD, Todd JA, Gough SC: Association of the interleukin-2 receptor alpha (IL2Ralpha)/CD25 gene region with Graves' disease using a multilocus test and tag SNPs. Clin Endocrinol (Oxf) 2007, 66(4):508-5I 2.

42. Lowe CE, Cooper JD, Brusko T, Walker NM, Smyth DJ, Bailey R, Bourget K, Plagnol V, Field S, Atkinson M, et al.: Large-scale genetic fine mapping and genotype-phenotype associations implicate polymorphism in the IL2RA region in type I diabetes. Nature Genetics 2007, 39(9): 1074-1082.

43. Tait KF, Marshall T, Berman J, Carr-Smith J, Rowe B, Todd JA, Bain $\mathrm{SC}$, Barnett $\mathrm{AH}$, Gough SC: Clustering of autoimmune disease in parents of siblings from the Type I diabetes Warren repository. Diabetic Medicine: A Journal of the British Diabetic Association 2004, 2 I (4):358-362.

\section{Pre-publication history}

The pre-publication history for this paper can be accessed here:

\section{http://www.biomedcentral.com/1471-2350/10/121/pre} pub
Publish with Bio Med Central and every scientist can read your work free of charge

"BioMed Central will be the most significant development for disseminating the results of biomedical research in our lifetime. "

Sir Paul Nurse, Cancer Research UK

Your research papers will be:

- available free of charge to the entire biomedical community

- peer reviewed and published immediately upon acceptance

- cited in PubMed and archived on PubMed Central

- yours - you keep the copyright

Submit your manuscript here:

http://www.biomedcentral.com/info/publishing_adv.asp
BioMedcentral 